\title{
Prevalence of endoparasitic infection in children and its relation with cholera prevention efforts in Mexico
}

\author{
Charles T. Faulkner, ${ }^{1}$ Benito Borrego Garcia, ${ }^{2}$ Michael H. Logan, ${ }^{3}$ \\ John C. New, ${ }^{1}$ and Sharon Patton ${ }^{1}$
}

\begin{abstract}
Objective. To investigate whether increased knowledge and use of public health measures promoted for cholera prevention is reflected in lower prevalence of parasitic infection in households in a community in the state of Tamaulipas, Mexico, that is close to the border with the United States of America.

Methods. Between 1994 and 1997, fecal samples from 438 children were collected through convenience sampling and then examined for helminth eggs/larvae and protozoan cysts as biologic indicators of household compliance with recommended cholera prevention measures. The suggested measures were to wash hands before meals and after defecation, to drink purified water, to wash fruits and vegetables, and to eat well-cooked food. In addition, information on the knowledge of and the use of cholera preventive measures was collected by interviews with adult informants in 252 households (186 of those households also provided a fecal sample for analysis).

Results. Parasitic infections occurred in 131 of the 438 children (30\%), who resided in 79 of the 186 households (42\%) that provided fecal samples. Giardia lamblia accounted for $12.5 \%$ of all infections. Infections with Hymenolepis nana, Ascaris lumbricoides, Trichuris trichiura, Enterobius vermicularis, Ancylostoma/Necator, Strongyloides stercoralis, Entamoeba coli, Entamoeba hartmanni, Entamoeba histolytica, Endolimax nana, and Iodamoeba bütschlii were also noted. Infected children were older and more often had an infected sibling. Households with three or more children were also more likely to have an infected child. The primary caregivers in the households where at least one child had a parasitic infection were distinguished by their inability to list at least three cholera prevention measures from memory. Conclusions. The $42 \%$ household prevalence of parasitic infection was relatively high and indicates that some residents of this community may not have fully embraced the public health education efforts promoted for prevention of cholera. The occurrence of nonpathogenic protozoan parasites such as Endolimax nana, Entamoeba coli, Entamoeba hartmanni, and I. bütschlii are important bioindicators for the persistence of unhygienic behaviors that increase the risk of cholera and other infectious diseases dependent on fecal-oral transmission. Information obtained by similar studies can be useful for monitoring compliance with community health and hygiene programs and may indicate the need to intensify educational efforts for the prevention of diarrhea associated with enteric pathogens that cannot be controlled by drugs alone.
\end{abstract}

Key words Cholera; parasitic diseases; health education; knowledge, attitudes, practice; Mexico.

1 University of Tennessee, Department of Comparative Medicine, Knoxville, Tennessee, United States of America. Send correspondence to: Charles T. Faulkner, Department of Comparative Medicine,
University of Tennessee, 2407 River Drive, Knoxville, Tennessee 37796-4543, United States of America; telephone: (865) 974-5718; fax: (865) 974-5640; e-mail: ctfaulkner@utk.edu
2 Médico veterinario zootecnista, Valle Hermoso, Tamaulipas, Mexico.

3 University of Tennessee, Department of Anthropology, Knoxville, Tennessee, United States of America. 
The epidemic spread of Vibrio cholerae, biotype El Tor, serotype Inaba, into Latin America in 1991 prompted a vigorous response from public health agencies at the international, national, state, and local community levels (1-4).

Education materials disseminated to the public described the nature of the disease and provided recommendations for prevention of infection by cholera and similar pathogens. Many residents of these countries became acutely aware of the fecal-oral route of cholera transmission and the importance of personal and household hygiene measures in maintaining health. Increased promotion of personal hygiene measures such as frequent handwashing, consumption of bottled or chemically treated water, and thoroughly washing fruits and vegetables prior to consumption helped mitigate the adverse impact of the cholera epidemic throughout Latin America, including Mexico (3-4). These efforts may have also had an additional effect on the community-wide prevalence of infection with endoparasitic helminths and protozoa dependent on the fecaloral transmission route. De la Sotta and colleagues (5) suggested that the Chilean cholera control program was responsible for a statistically significant decrease in intestinal parasitoses diagnosed at hospitals in the city of Santiago during the 3-year period that followed a national campaign. However, this association may have been coincidental because Santiago residents were not interviewed to determine if they knew or used any of the anti-cholera recommendations.

We undertook our research to investigate the impact that a locally administered program to prevent cholera had on the prevalence of endoparasitic infection in households of a small community in the state of Tamaulipas, in northeastern Mexico. Like de la Sotta and colleagues (5), we were intrigued by the possibility that increased community awareness and utilization of cholera prevention measures could reduce the prevalence of intestinal parasitic infections. We hypothesized that household compliance with the educational initiative undertaken in this community would be reflected in lower occurrence of infection with intestinal protozoan and helminth parasites because their transmission is facilitated by the same unhygienic behaviors that increase risk for cholera.

These unhygienic behaviors include inadequate hand-washing, drinking contaminated water, eating improperly washed fruits and vegetables, and promiscuous defecation habits. The occurrence of nonpathogenic protozoan parasites such as Endolimax nana, Iodamoeba bütschlii, Entamoeba coli, and Entamoeba hartmanni in populations targeted by interventions to prevent cholera are important bioindicators for unhygienic behavior because these parasites do not produce clinical disease and are not treated by physicians. Use of these parasites as bioindicators of unhygienic behavior provided us with a method for objectively evaluating the quality of information on the knowledge and practice of cholera preventive measures obtained from interviews with the primary caregivers in participating households. This investigation offered a unique opportunity to examine an important dimension of human behavior by comparing what informants say they do with what they actually do. The information obtained through this research can be used by public health workers to monitor compliance with community health and hygiene programs, and it may indicate the need to intensify educational efforts for prevention of diarrhea associated with enteric pathogens such as cholera, Salmonella, Cryptosporidium sp., and Giardia lamblia that cannot be controlled by drugs alone.

\section{METHODS}

This study was carried out between 1994 and 1997 in Valle Hermoso, Tamaulipas, Mexico, a community of 39004 persons located $45 \mathrm{~km}$ south of the border with the United States of America (6-7). Employment and investment opportunities arising from recent industrial growth and increased trade with the United States have prompted people to relocate from sur- rounding communities and establish homes in neighborhoods developing on the outskirts of Valle Hermoso. Constructed of concrete block or wood frame with plywood or flat-board siding, the houses in these neighborhoods have between one and three rooms. Electrical utilities and running water inside the house are available in approximately $90 \%$ of the households (7). Outside latrines are the primary method for disposal of fecal waste, and only $19 \%$ of the households have indoor toilets (7).

The decision to conduct this investigation in Valle Hermoso was motivated primarily by our preexisting relationship with local government officials and health department personnel. The relatively small size of the community and its convenient distance from the border with the United States were secondary considerations that made this an attractive place for the investigation.

\section{Household enlistment and data collection}

All of the households in the study were located in neighborhoods that had been the focus of recent public health education initiatives to reduce childhood morbidity from cholera and diarrheal disease produced by parasitic and other infectious enteric agents. The ongoing educational effort was initiated in 1993, that is, the year before the start of this investigation, and it was carried out by local committees of volunteer health promoters trained to work under the supervision of nurses from a Valle Hermoso health center operated by the Government's Secretariat of Health (Secretaría de Salud). Having the health promoters structure already in place maximized our access to households and helped assure rapport with subjects.

Some of the participants enlisted in the study during open meetings with health educators and two of the authors (CTF and BBG). At these meetings the project objectives were described by the two authors (CTF and $\mathrm{BBG})$, and the participants received instructions for collecting fecal speci- 
mens from resident children for parasitologic analysis. Other participants were recruited during neighborhood public health clinics conducted under the auspices of the Valle Hermoso health center.

Participation in the study was strictly voluntary, with no monetary incentives offered. Informed consent for all household participants was obtained in compliance with the University of Tennessee Institutional Review Board guidelines for research involving human subjects. Participants were informed that all children who tested positive for clinically significant parasitic infections would be referred to the Valle Hermoso health center, where treatment would be provided at no cost. The households surveyed in this study constituted a convenience sample.

Small teams of neighborhood health promoters, nurses, and the authors interviewed household informants during door-to-door surveys. Questionnaires were used to interview the primary caregiver (PC) in each participating household. The information that was collected included: age and sex of the informant; the age, the sex, and the number of resident children; source of drinking water; and facilities for disposal of fecal waste. Information was also collected on household income, based on the occupation of the head of the household, and on homeownership. Knowledge of cholera prevention measures was assessed by asking informants to recall these recommendations from memory:

1) wash hands after defecation and before meals

2) wash fruits and vegetables before consumption

3) cook all foods well, especially seafood

4) only drink water that has been boiled or purified by filtration or chemical treatment

Each informant was asked, "Do you know the government recommendations for the prevention of cholera?" Informants answering in the affirmative were then asked to list the recommendations from memory.
Use of the preventive measures in the households was classified as consistent based on the response that they were used all of the time, or inconsistent based on the response that they were either used some of the time or never used.

When the questionnaire was administered, each PC received explicit instructions on how to collect fecal samples from their children and to label, for each sample submitted, plastic bags (provided by the authors) with the child's name, sex, age, family name, and name of the neighborhood. The fecal samples were collected by the authors 24 hours later, taken to a field laboratory, divided into equal portions and transferred to fecal transport vials (Meridian Diagnostics, Cincinnati, Ohio, United States) that contained either $10 \%$ buffered neutral formalin (BNF) or polyvinyl alcohol (PVA), and then transported to the University of Tennessee Clinical Parasitology Laboratory. Samples preserved in BNF were analyzed for diagnostic stages of endoparasites by the centrifugal flotation method, with saturated zinc sulfate (specific gravity 1.18 ) and Sheather's sucrose (specific gravity 1.26) solutions as flotation media (8). Eggs and cysts of helminths and protozoa were identified based on their characteristic morphology and size, with the aid of diagnostic reference manuals (8-11). Fecal smears made from PVA-fixed samples were stained with the modified trichrome staining technique and examined to confirm the identification of protozoan cysts recognized from the zinc sulfate flotation (11). All samples were also macroscopically examined for blood, mucus, spontaneously passed worms, tapeworm segments, and fly larvae.

\section{Study design, analytical units, and statistical methods}

This investigation was a cross-sectional study based on convenience sampling (12). Endoparasitic infections in children (i.e., positive or negative) were compared by age and sex of the child and the presence or absence of an infected sibling. The occurrence of endoparasitic infection in households was compared by the number of resident children, ability of the PC to recall cholera prevention measures, selfreported frequency of their use, drinking water source, and household facilities for fecal waste disposal. Participants consisted of children $\leq 16$ years old $(n=438)$ from whom fecal samples were examined for parasitic infection by collection on a single occasion, and the household PCs $(n=242)$ interviewed with the household health and hygiene questionnaire administered by members of the research team.

Data were analyzed by appropriate parametric and nonparametric statistical methods with the InStat 3 software package (GraphPad Software, San Diego, California, United States) for the Microsoft Windows 95 operating system. Unpaired Student's $t$ tests were used to test for any significant difference in the mean age of infected and uninfected children, and for agerelated differences in infection with specific parasite species. Single factor analysis of variance (ANOVA) was used to test for differences in mean age among informants from three groups: infected households $(n=79)$, uninfected households $(n=107)$, and a smaller group of informants whose household infection status was unknown because they declined to submit fecal samples for parasite analysis $(n=56)$. ANOVA was also used to test for any difference in the weekly mean income of these three household groups. The statistical association of parasitic infection with other nominal and discrete variables (e.g., residing in the household with an infected sibling, the number of resident children, and the ability of the PC to recall cholera prevention measures) was evaluated with Fisher's exact test. Level of significance $(\alpha)$ was set a priori at $\leq 0.05$. Prevalence odds ratios were calculated to estimate the strength of association between the occurrence of parasitic infection and suspected exposures (e.g., the presence of an infected child in the household, inability to recall at least three cholera prevention measures, or inconsistent use of preventive measures) (12). 


\section{RESULTS}

\section{Parasitic infections in children}

Fecal samples of 438 children were analyzed for endoparasitic infection (Table 1). The mean age of the children was 6 years. The number of fecal samples was approximately equal for males and females, and there was no significant difference in age by sex (Table 1). Evidence of parasitic infection was found in $30 \%$ of all examined samples (Table 1). Endoparasitic infections were indicated by the occurrence of helminth eggs or larvae or protozoan trophozoites or cysts in a fecal sample collected on a single occasion. Infection status was not associated with the sex of the child despite the observation that slightly more female children had positive fecal examinations than did male children (Table 1). Infected children were significantly older than were uninfected children (Table 1).

In terms of specific parasites, children infected with Entamoeba hartmanni were significantly older than were children without this parasite (Table 2). Parasites found in children older than the overall mean age were Hymenolepis nana, Trichuris trichiura, Enterobius vermicularis, Entamoeba coli, Endolimax nana, and Iodamoeba bütschlii (Table 2). However, this association was not statistically significant. More of the children infected with Ascaris lumbricoides and Giardia lamblia were younger than the overall mean age, but this association was also not statistically significant (Table 2). Infected children were 2.9 times as likely to have an infected sibling as were uninfected children (Table 3).

Infections with two or more parasites occurred in $31 \%$ of all positive children tested (Table 1). The occurrence of multiple infections was not associated with the age or sex of the child (Table 1) or with the infection status of their siblings (Table 3). The sample sizes did not allow for analysis of parasite species distributions within households or neighborhoods or of their co-occurrence with other parasite species.

\section{Parasitic infection in households}

The occurrence of parasitic infection in households was based on 186 households that provided fecal samples for analysis. Of the 186 households, 79 of them $(42 \%)$ had at least one infected child. The other 107 households were considered uninfected based on a single negative fecal examination from all children residing in the household (Table 4). Informants from these 186 households provided information on their knowledge and use of cholera prevention measures and on other characteristics relevant to understanding the distribution of parasitic infections in their children. This information was also obtained from 56 additional informants whose household infection status was unknown because they declined to submit fecal samples from their children following the interview. Although these informants cannot be regarded as a "control" group in the true sense of the definition, they contributed an additional dimension for describing the demographic character-

TABLE 1. Age and gender data on 438 children $\leq 16$ years old analyzed for endoparasitic infection, Valle Hermoso, Tamaulipas Mexico, 1994-1997

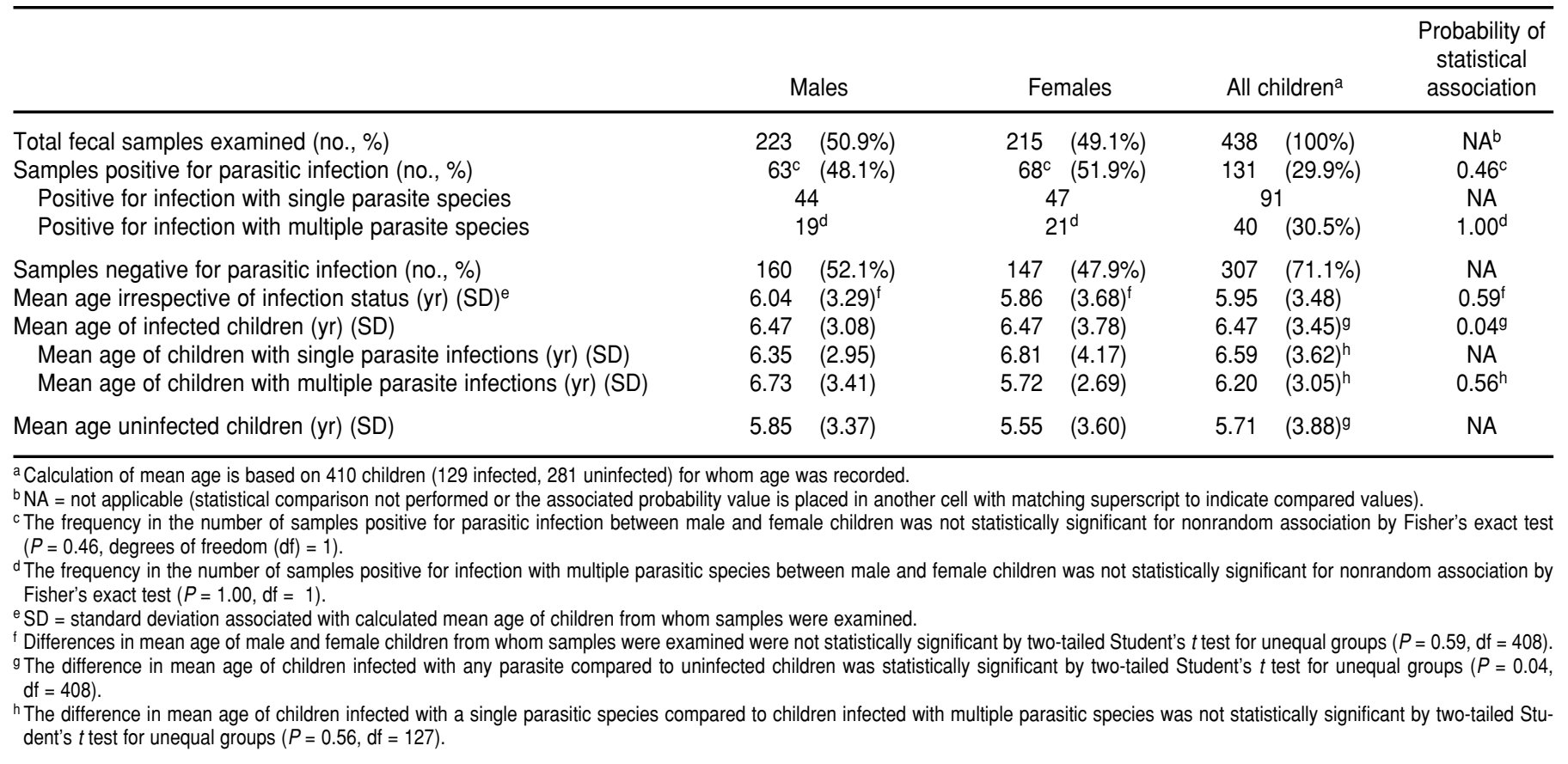


TABLE 2. Frequency of endoparasitic infections in children $\leq 16$ years of age) by age, Valle Hermoso, Tamaulipas, Mexico. 1994-1997

\begin{tabular}{|c|c|c|c|c|c|c|c|}
\hline \multirow[b]{2}{*}{ Parasite species } & \multicolumn{2}{|l|}{ Samples } & \multicolumn{2}{|c|}{$\begin{array}{c}\text { Age (yr) of } \\
\text { infected children }\end{array}$} & \multicolumn{2}{|c|}{$\begin{array}{c}\text { Age }(y r) \text { of } \\
\text { uninfected children }\end{array}$} & \multirow{2}{*}{$\begin{array}{c}\text { Probability of } \\
\text { inequality in } \\
\text { mean age }\end{array}$} \\
\hline & Positive/Examined & $\%$ & Meana $^{a}$ & $\mathrm{SD}^{\mathrm{b}}$ & Meana & $\mathrm{SD}^{\mathrm{b}}$ & \\
\hline \multicolumn{8}{|l|}{ Protozoa } \\
\hline Giardia lamblia & $55 / 438$ & 12.55 & 5.70 & 3.17 & 5.99 & 3.53 & 0.582 \\
\hline Entamoeba coli & $27 / 438$ & 6.16 & 6.87 & 3.40 & 5.89 & 3.49 & 0.158 \\
\hline Entamoeba hartmanni & $24 / 438$ & 5.47 & 8.22 & $3.89^{c}$ & 5.81 & $3.41^{c}$ & $0.001^{\mathrm{c}}$ \\
\hline Entamoeba histolytica & $1 / 438$ & 0.22 & $\mathrm{NA}^{\mathrm{d}}$ & NA & NA & NA & NA \\
\hline Endolimax nana & $23 / 438$ & 5.25 & 6.57 & 3.06 & 5.91 & 3.51 & 0.379 \\
\hline lodamoeba bütschlii & $10 / 438$ & 2.28 & 7.70 & 4.00 & 5.91 & 3.47 & 0.109 \\
\hline \multicolumn{8}{|l|}{ Helminths } \\
\hline Hymenolepis nana & $28 / 438$ & 6.39 & 7.07 & 2.72 & 5.87 & 3.52 & 0.079 \\
\hline Ascaris lumbricoides & $16 / 438$ & 3.65 & 4.50 & 2.37 & 6.01 & 3.51 & 0.0 \\
\hline Trichuris trichiura & $6 / 438$ & 1.36 & 6.83 & 4.26 & 5.94 & 3.48 & 0.535 \\
\hline Enterobius vermicularis & $6 / 438$ & 1.36 & 6.16 & 1.83 & 5.95 & 3.50 & 0.881 \\
\hline Ancylostoma/Necatore & $1 / 438$ & 0.22 & NA & NA & NA & NA & NA \\
\hline Strongyloides stercoralis & $1 / 438$ & 0.22 & NA & NA & NA & NA & NA \\
\hline
\end{tabular}

TABLE 3. Frequency of parasitic infection in children and households according to residence in a household with an infected sibling, and relative number of children in household, Valle Hermoso, Tamaulipas, Mexico, 1994-1997

\begin{tabular}{|c|c|c|c|c|c|}
\hline \multirow[b]{2}{*}{ Parasite infection status } & \multirow{2}{*}{\multicolumn{2}{|c|}{ Residence in household with: }} & \multirow{2}{*}{$\begin{array}{l}\text { Prevalence } \\
\text { odds ratio }\end{array}$} & \multicolumn{2}{|c|}{$95 \%$ confidence limit } \\
\hline & & & & Lower & Upper \\
\hline & Infected sibling & Uninfected sibling & & & \\
\hline Child infected & 75 & 38 & $2.882^{a}$ & 1.808 & 4.592 \\
\hline \multirow[t]{2}{*}{ Child uninfected } & 100 & 146 & & & \\
\hline & Infected sibling & Uninfected sibling & & & \\
\hline Children with multiple parasite species & 24 & 49 & $1.020^{b}$ & 0.483 & 2.373 \\
\hline \multirow[t]{2}{*}{ Children with single parasite species } & 12 & 25 & & & \\
\hline & 3 or more children & 1 or 2 children & & & \\
\hline Household infected & 50 & 29 & $4.637^{c}$ & 2.481 & 8.668 \\
\hline Household uninfected & 29 & 78 & & & \\
\hline
\end{tabular}

istics and range of information provided by the study participants.

Married females, who had a mean age of 31 years, accounted for $90 \%$ of the persons interviewed in the three groups of household informants (Table 4). These demographic characteristics were similar for informants from infected and uninfected households and did not differ appreciably from the participants $(n=56)$ whose household infection status was unknown (Table 4). Mean weekly household income and homeownership for participants in the study did not differ significantly among the three groups (Table 4). Although flush toilets were more frequent in uninfected households, their absence was not associated with household infection status (Table 4).

Infection status was significantly associated with the number of children residing in the household. Households with three or more children were 4.6 times as likely to have an infected child as compared to households with fewer children (Table 3). 
TABLE 4. Characteristics of informants and households studied for parasitic infection and its relation to cholera prevention measures in Valle Hermoso, Tamaulipas, Mexico. 1994-1997

\begin{tabular}{|c|c|c|c|c|c|}
\hline \multirow[b]{2}{*}{ Informant and household characteristics } & \multicolumn{3}{|c|}{ Household infection status } & \multirow{2}{*}{\multicolumn{2}{|c|}{$\begin{array}{l}\text { Probability of } \\
\text { statistical } \\
\text { association }\end{array}$}} \\
\hline & $\begin{array}{l}\text { Infected } \\
(n=79)\end{array}$ & $\begin{array}{l}\text { Uninfected } \\
(n=107)\end{array}$ & $\begin{array}{l}\text { Unknown }{ }^{\mathrm{a}} \\
(n=56)\end{array}$ & & \\
\hline \multicolumn{6}{|l|}{ Household informants } \\
\hline Mean age (yr) (SD) b & $31.40(8.16)$ & 31.37 (8.58) & $31.83(11.83)$ & \multicolumn{2}{|c|}{$0.951^{c}$} \\
\hline Female (no., \%) & $73(92 \%)$ & $96(90 \%)$ & $50(89 \%)$ & \multicolumn{2}{|c|}{$N A^{d}$} \\
\hline Male (no., \%) & $6(8 \%)$ & $11(10 \%)$ & $6(11 \%)$ & \multicolumn{2}{|c|}{ NA } \\
\hline Homeownership (no., \%) & & & \multirow{2}{*}{$\begin{array}{l}\text { Prevalence } \\
\text { odds ratio }\end{array}$} & \multicolumn{2}{|c|}{$\begin{array}{c}95 \% \text { confidence } \\
\text { limit }\end{array}$} \\
\hline Facilities for fecal waste disposal & Infected ${ }^{\text {h }}$ & Uninfected ${ }^{\mathrm{h}}$ & & Lower & Upper \\
\hline Outside latrine & 63 & 77 & \multirow{2}{*}{$1.86^{\mathrm{h}}$} & \multirow{2}{*}{\multicolumn{2}{|c|}{0.849}} \\
\hline Flush toilet in house & 11 & 25 & & & \\
\hline \multicolumn{6}{|c|}{$\begin{array}{l}\text { a Household infection status was unknown because informants from these households declined to submit fecal samples for parasite analysis. } \\
\text { b SD }=\text { standard deviation. } \\
\text { c Difference in mean age of informants from households of infected, uninfected and unknown infection status was not statistically significant by single factor analysis of variance (ANOVA) }(P= \\
0.951 \text {, degrees of freedom }(\mathrm{df})=239) \text {. } \\
\text { d NA = not applicable, statistical comparison not performed. } \\
\text { e The exchange rate for pesos was } 7.3 \text { pesos }=U S \$ 1.00 \text { as of January } 22,1996 \text {. } \\
\text { f Difference in mean weekly income of households of infected, uninfected, and unknown infection status was not statistically significant by ANOVA }(P=0.352, \mathrm{df}=239) \text {. } \\
9 \text { Difference in the frequency of homeownership among households of infected, uninfected, and unknown infection status was not significantly different for nonrandom association by chi-square } \\
\text { test }(P=0.60 \text {, df }=2) \text {. } \\
\text { h Facilities for fecal waste disposal not reported for all households. Household infection status and access to facilities for fecal waste disposal was not statistically significant for nonrandom as- } \\
\text { sociation by Fisher's exact test }(P=0.13, \mathrm{df}=1) \text {. }\end{array}$} \\
\hline
\end{tabular}

\section{Parasitic infection and knowledge and use of cholera prevention measures}

Informants in each of the participating household groups were knowledgeable regarding the recommendations promoted for cholera prevention as indicated by their ability to provide at least one preventive measure from memory. Seventy-five percent of all persons interviewed were able to recall at least one preventive measure from memory. The open-ended nature of our request to list the cholera preventive measures produced many individual responses that were thematically consistent with three general classes of interventions related to treatment of drinking water, personal hygiene (e.g., hand-washing before meals and following defecation), and food hygiene (e.g., washing fruits and vegetables, and cooking all food well). A fourth class of "other preventive measures" included the admonition to avoid consumption of food offered by street vendors (no come comida en la calle), and that following advice from nurses, brochures, and radio broadcasts was an important intervention for cholera prevention. These preventive measures were listed by single informants and could not be consistently categorized with respect to the other thematic classes.

Recall of these general thematic classes of cholera preventive measures was similar between informants from infected and uninfected households (Table 5). Informants from 88 uninfected households were able to recall a total of 241 preventive measures from memory, and informants from 57 infected households listed 131 total preventive measures (Table 5). However, the frequency with which preventive measures from the thematic classes were listed by informants was not significantly associated with household infection status (Table 5).

Drinking water treatments recalled from memory by informants included boiling, filtering, adding a small amount of chlorine bleach, and the admonition that drinking water should not be taken directly from the faucet without treatment or filtration. Although informants from 5 of the 145 households mentioned that the addition of cloro (i.e., household bleach, $5.25 \%$ sodium hypochlorite) was an important method for treating drinking water, only a single informant was able to recall from memory that two drops of cloro per liter were required to adequately disinfect drinking water.

Personal hygiene measures recalled from memory included hand-washing practices before meals and after using the bathroom. The importance of using designated latrines for defecation and the admonishment that defecation should not be done freely in the environment was also considered as a preventive measure associated with personal hygiene.

Food hygiene measures recalled by informants included the recommendations of washing fruits and vegetables so as to remove contaminants and of cooking all food well. Hand-washing that was mentioned specifically in connection with food preparation (e.g., 
before preparing or cooking food) was considered a preventive measure associated with food hygiene. The basis for this distinction was that hand-washing prior to food preparation prevented the spread of infection to others, while hand-washing before meals or after using the bathroom was important for prevention of infection to oneself.

Household infection status was not statistically associated with the frequency of the different classes of cholera preventative measures recalled (Table 5).

The ability to list at least three preventive measures was significantly associated with household infection status (Table 6). Informants who were unable to list at least three cholera preventive measures were two times as likely to have an infected child in the household (Table 6). Household infection status was not statistically associated with informant's self-reported consistent or inconsistent use of cholera prevention measures (Table 6). However, households with parasitic infections were five times as likely to obtain their drinking water directly from the faucet without treatment.

Informants who were unable to recall at least three preventive measures from memory were 2.8 times as likely to self-report inconsistent use of the measures in the household (Table 7). Similarly, informants who self-reported inconsistent use of cholera preventive measures in their households were 3.7 times as likely to obtain their drinking water directly from the faucet without treatment (Table 7).

\section{DISCUSSION}

The 1991 threat of epidemic cholera provided Government public health authorities in Mexico with the impetus to implement a community-based intervention strategy for promoting personal and food hygiene measures to prevent infection with cholera and other pathogens associated with diarrheal disease $(2,4)$. Widespread adoption of recommendations to frequently wash hands following defecation and prior to meal consumption, drink water that has been purified or treated, and eat well-cooked food may have been influential in the low occurrence of parasitic infection observed in the northeastern Mexican community reported in this study.

Promoting personal hygiene measures for preventing cholera infection in Chile was believed to be responsible for reducing the prevalence of infection with intestinal parasites that de-

TABLE 5. Frequency of cholera preventive measures (grouped according to general thematic class) recalled from memory by 145 household informants during interviews, Valle Hermoso, Tamaulipas, Mexico, 1994-1997

\begin{tabular}{|c|c|c|c|c|c|}
\hline \multirow{3}{*}{$\begin{array}{c}\text { Thematic class of cholera } \\
\text { prevention measure }\end{array}$} & \multicolumn{4}{|c|}{$\begin{array}{l}\text { Household parasite } \\
\text { infection status }\end{array}$} & \multirow{3}{*}{$\begin{array}{l}\text { Probability of } \\
\text { statistical association }\end{array}$} \\
\hline & \multicolumn{2}{|c|}{$\begin{array}{l}\text { Infected } \\
(n=57)\end{array}$} & \multicolumn{2}{|c|}{$\begin{array}{l}\text { Uninfected } \\
(n=88)\end{array}$} & \\
\hline & No. & $\%$ & No. & $\%$ & \\
\hline Treatment of drinking water & 32 & 24 & 44 & 18 & \\
\hline Personal hygiene & 51 & 39 & 100 & 41 & \\
\hline Food hygiene & 41 & 31 & 85 & 35 & \\
\hline Other preventive measures & 7 & 5 & 12 & 5 & \\
\hline Total responses & 131 & $99^{a}$ & 241 & $99^{a}$ & $0.544^{b}$ \\
\hline
\end{tabular}

a Percentage for total responses adds to $99 \%$ because of rounding in the percentages for the general thematic classes.

${ }^{b}$ Frequency of cholera preventive measures (grouped according to general thematic class) recalled by household informants and household infection status was not statistically significant for nonrandom association by chi-square test for independence $(P=0.544$, degrees of freedom $=3)$.

TABLE 6. Prevalence of parasitic infection according to informant's ability to recall cholera preventive measures from memory, selfreported usage of cholera prevention measures, and source of household drinking water, Valle Hermoso, Tamaulipas, Mexico. 1994-1997

\begin{tabular}{|c|c|c|c|c|c|}
\hline \multirow[b]{2}{*}{ Variable } & \multicolumn{2}{|c|}{ Household infection status } & \multirow{2}{*}{$\begin{array}{c}\text { Prevalence } \\
\text { odds ratio }\end{array}$} & \multicolumn{2}{|c|}{$95 \%$ confidence limit } \\
\hline & Infected & Uninfected & & Lower & Upper \\
\hline \multicolumn{6}{|c|}{ Ability to recall three or more cholera prevention measures from memory } \\
\hline Not able & 38 & 42 & $2.018^{a}$ & 1.067 & 3.819 \\
\hline Able & 26 & 58 & & & \\
\hline \multicolumn{6}{|c|}{ Self-reported household use of cholera prevention measures } \\
\hline Inconsistent & 23 & 36 & $0.865^{b}$ & 0.430 & 1.792 \\
\hline Consistent & 31 & 42 & & & \\
\hline \multicolumn{6}{|l|}{ Source of drinking water used in household } \\
\hline Untreated, used directly from faucet & 30 & 12 & $5.111^{c}$ & 2.393 & 10.914 \\
\hline Bottled, chemically treated, or filtered & 45 & 92 & & & \\
\hline
\end{tabular}

${ }^{a}$ The frequency of informants able to recall three or more cholera preventive measures and household infection status was statistically significant for nonrandom association by Fisher's exact test $(P=0.037$, degrees of freedom $(\mathrm{df})=1)$.

b The frequency of informants' self-reported household use of cholera preventive measures and household infection status was not statistically significant for nonrandom association by Fisher's exact test $(P=0.724, \mathrm{df}=1)$.

${ }^{c}$ The frequency of households using untreated water and household infection status was statistically significant for nonrandom association by Fisher's exact test $(P<0.0001, \mathrm{df}=1)$. 
TABLE 7. Self-reported usage of cholera preventive measures in household according to informant's ability to recall preventive measures from memory and source of drinking water used in household, Valle Hermoso, Tamaulipas, Mexico. 1994-1997

\begin{tabular}{|c|c|c|c|c|c|}
\hline & \multicolumn{2}{|c|}{$\begin{array}{l}\text { Self-reported household use } \\
\text { of cholera prevention measures }\end{array}$} & \multirow{2}{*}{$\begin{array}{l}\text { Prevalence } \\
\text { odds ratio }\end{array}$} & \multicolumn{2}{|c|}{$95 \%$ confidence limit } \\
\hline & Inconsistent & Consistent & & Lower & Upper \\
\hline \multicolumn{6}{|c|}{ Ability to recall three or more cholera prevention measures from memory } \\
\hline Not able & 37 & 30 & $2.775^{a}$ & 1.359 & 5.666 \\
\hline Able & 20 & 45 & & & \\
\hline \multicolumn{6}{|l|}{ Source of drinking water used in household } \\
\hline
\end{tabular}

pend on the fecal-oral transmission route (5). These conclusions were based on comparisons of the total number of parasitic infections diagnosed in Santiago area hospitals in the 3 years preceding and the 3 years following a national cholera prevention campaign. However, interviews were not conducted with cases and noncases to determine if these persons had actual knowledge of the ways to prevent cholera, or if the prevention methods were used in their households. The absence of this information limits the usefulness of the observation because the association may be coincidental and because the findings are potentially unrelated.

In this study in Mexico we investigated the hypothesis that children residing in households where the primary caregiver had knowledge of Government-promoted cholera prevention recommendations were less likely to be infected with intestinal parasites dependent on fecal-oral transmission. Fecal samples from resident children were examined for parasitic infection, and these data were used as biological indicators of household knowledge of and compliance with cholera prevention measures. The fecaloral nature of transmission for many intestinal protozoan and helminth parasites that infect humans is well established (13). However, recognition that nonpathogenic protozoan species can serve as biological indicators of how well individuals and households fol- low recommendations to engage in frequent hand-washing and other healthpromoting behaviors for prevention of infectious enteric diseases has not been the subject of systematic investigation despite the widespread acknowledgment that parasitic infections are evidence of fecal-oral contamination.

Species such as Entamoeba coli, Entamoeba hartmanni, Iodamoeba bütschlii, and Endolimax nana are especially well suited to this role because they do not cause clinical disease and are not targeted for treatment by physicians or community-based drug distribution programs. Infections are indirectly facilitated in susceptible hosts by consumption or preparation of food with unwashed hands following defecation or changing an infant's diaper. The occurrence of these nonpathogenic protozoa in the feces of individuals sharing the same household is indirect evidence of a range of behaviors necessary to maintain fecal-oral transmission of the parasites between infected and susceptible persons.

The results of this investigation indicate that children residing in households where the primary caregiver was unable to recall from memory at least three cholera prevention measures were two times as likely to be infected with an intestinal parasite. Although we cannot posit a clearly defined causeand-effect relationship between these variables, the significance of the association suggests that greater awareness of the hygienic measures that reduce risk of cholera infection is reflected in the lower frequency of other enteric pathogens that also depend on the fecal-oral transmission route.

The overall prevalence of endoparasitic infection in the Valle Hermoso children was $30 \%$. Parasites capable of producing disease accounted for $20 \%$ of the infections. Giardia lamblia, a flagellated protozoan associated with diarrheal disease, was the most prevalent of the pathogenic species. Although G. lamblia infection can be treated with metronidazole and albendazole, which are available as "over the counter" drugs in Mexican pharmacies, the parasite is highly infectious and rapidly spread from one infected person to another. Such treatment and control efforts are frustrated by the parasite's 5day to 14-day lifecycle and its ability to parasitize human and nonhuman hosts without causing disease (13). Asymptomatic infection in these hosts is an important reservoir for spread of infectious cysts to susceptible persons. Effective control of the parasite requires a sustained effort to break the cycle of infection and re-infection with effective chemotherapy and promotion of frequent hand-washing and other personal hygiene measures.

The lower prevalence of infections with Ascaris lumbricoides and Trichuris trichiura reflects the effect of suppressive targeted chemotherapy for schoolage children. In Valle Hermoso, schoolage children (at least 5 years old) were treated with albendazole (a single dose 
of 400 milligrams) during the study period as part of the Government's parasite control program. However, the fecal sample collection activities for our study were conducted at least 90 days following that treatment, so that the children had sufficient time to develop mature infections with $A$. lumbricoides and T. trichiura (13). It is well established that the long-term effect of suppressive drug therapy for schoolage children should result in a net reduction in the number of infective eggs available in the environment for reinfection of new hosts in the community (14). However, the persistence of T. trichiura infections in school-age children who should be benefiting from periodic administration of anthelmintics indicates continuing transmission of the parasite in the community and raises an important issue regarding the efficacy of these drug treatments for control of this parasite. The median cure rate for T. trichiura is only $38 \%$, although individual studies report cure rates that range from $4.9 \%$ to $99.3 \%$ (15). This widespread variation in efficacy indicates that periodic surveillance is necessary to monitor the success of anthelmintic treatment programs for school-age children, with an eye toward the potential emergence of drug-resistant parasite populations.

Infections with nonpathogenic protozoan species such as E. coli, E. hartmanni, E. nana, and I. bütschlii and the tapeworm Hymenolepis nana indicate the persistence of inadequate hygienic behavior in specific households. The prevalence of these species is probably not affected noticeably by the semiannual albendazole treatments used in the school chemotherapy program. That is because the drug has limited efficacy against these parasites, and the parasites are not treated by physicians because they are not associated with clinical disease. The fecal-oral nature of transmission and the relatively short period of time required to establish infections suggests that any chemotherapeutic benefit would be short-lived in the absence of sustained personal hygiene measures required to break the cycle of infection and reinfection of new hosts.
Infected children were significantly older and almost three times as likely to have an infected sibling as were children from uninfected households. Households with three or more children were nearly five times as likely to have an infected child as compared to households with two or fewer children. It is intuitive that the risk of parasitic infection in children should increase with age as they become more ambulatory and their school and play activities take them farther from the watchful eye of their mothers and other caregivers. Infected siblings also provide a reservoir and a mechanism for introducing parasites that can be shared by all family members in the household (16). The strained supervisory abilities of caregivers in households with numerous children is a plausible explanation for the fact that increased family size is an exposure variable associated with parasitic infection.

In Valle Hermoso the majority of household informants were able to recall from memory at least one intervention for preventing cholera infection. The ability to recall specific recommendations for treatment of drinking water, personal hygiene, and food hygiene was similar for informants from uninfected and infected households. Personal hygiene measures, such as hand-washing before meals and after using the bathroom, were listed with the highest frequency. Food hygiene measures, such as washing fruits and vegetables and cooking foods completely, were second in frequency. Households infrequently mentioned preventive measures related to seafood and consumption of food from street vendors. This was interesting, given the important roles of these two areas of risk in the epidemiology of cholera and foodborne disease outbreaks (17-18).

Informants from uninfected households were significantly more likely to be able to recall at least three preventive measures. The lack of association between household infection status and self-reported use of cholera preventive measures was not surprising. It likely reflects a bias toward providing interview teams with the perceived "cor- rect" answer, that is, that preventive measures were employed in the household on a consistent basis. However, informants able to list at least three preventive measures from memory were also more likely to report consistent use of the preventive measures in the household. An association between self-reported inconsistent use of the preventive measures in households and the use of untreated drinking water was noted. Together, these observations suggest that the ability to recall specific preventive measures may be a valid proxy for household use of those measures, and this is reflected by the lower prevalence of parasitic infection.

The impact of Mexico's national cholera prevention campaign on the occurrence of endoparasitic infection in Valle Hermoso cannot be directly assessed in the absence of communitywide parasite prevalence data collected prior to 1990. Statistical data compiled by state health departments in Mexico are of limited use because they are based on cases of parasitic infection that require the attention of medical authorities and thus do not include nonpathogenic protozoan parasites that are not associated with clinical disease and treated. Communitywide parasite surveys conducted in the Mexican states of Morelos, Nuevo Leon, and Sinaloa (19-23) are likewise of limited utility because of differences in study objectives, community hygiene, standard of living, and access to potable water. The relatively low $(30 \%)$ prevalence of parasitic infection found in the samples examined during this study indicates that many residents of this community have benefited from public health education efforts promoted as a response to the threat of epidemic cholera. However, the $42 \%$ household prevalence of parasitic infection is troubling in light of the apparent acceptance and adoption of the message that "hygiene is health," which is evident throughout the community, with it painted on walls in cafes, restaurants, and public restrooms. Health and hygiene educational posters illustrating the ways to prevent cholera and other diarrheal diseases are similarly displayed in neighborhood health clinics 
and the small convenience stores frequented by residents.

There was an association between household infection and informants being unable to recall at least three cholera prevention measures. This indicates the persistence of the unhygienic behaviors that maintain fecaloral transmission of parasitic species between infected and susceptible household members. By persisting in these risky behaviors, the residents of these households are at increased risk for morbidity associated with an outbreak of epidemic cholera as well as other infectious parasitic and diarrhearelated pathogens.

The conclusions drawn from this investigation are subject to several limitations. The convenience sampling methodology employed for collecting fecal samples and interviewing household informants limits the ability to generalize from this study to the rest of the residential population of Valle Hermoso and similar communities in northeastern Mexico. Although this investigation was carried out in specific neighborhoods chosen for their cooperation with public health nurses and local health promoters, this bias was acceptable because the research investigated the recall and use of cholera preventive measures in community households. An important characteristic for participation in the study was the opportunity for exposure to Government public health education programs. All participants were included without regard to income, homeownership, or family size.

Interviews were also conducted with a limited number of primary caregivers in households whose infection status was unknown because they declined to submit fecal samples for parasitologic analysis. Neither the household characteristics nor the range of knowledge and use of cholera prevention measures provided by these subjects differed appreciably from the study participants who did provide a fecal sample. This finding suggests that the data and results described in this paper are a reasonable quick overview or "snapshot" of the health experience in the community at the time of the investigation.

The cross-sectional study design limits the ability to ascertain whether the onset of parasitic infection in the household is an antecedent or a consequence of the exposure variables defined in this study. The prevalence odds ratio is the preferred measure of association because the onset of disease is difficult to determine and because the duration of the outcome (parasitic infection) is not affected by exposure status (12). Similarly, reliance on a single fecal sample for differentiating infected and uninfected subjects may introduce a misclassification bias. The sensitivity of a single fecal sample is generally sufficient to identify infected persons with symptoms of parasitic disease (24-25). Examination of multiple fecal samples collected on successive days has been shown to increase the sensitivity to detect parasitic infections in asymptomatic persons (26). The prevalence of parasitic infection may be underrepresented in this study because fecal samples were collected from healthy persons without symptoms of parasitic disease. Households in which a single child was examined are most susceptible to misclassification as uninfected. The greater likelihood of parasitic infection in households with at least three children may be confounded by examination of a greater number of fecal samples from those households, and it may not necessarily reflect increased probability of parasite transmission between infected and susceptible family members.

Despite these limitations, this comparative analysis of parasitic infection and its relation with cholera prevention efforts in this community provides a useful context for developing testable hypotheses for future investigations based on cohort or case-control study designs. Although costly in terms of money and labor, periodic surveillance for the nonpathogenic protozoan parasites as bioindicators can be a useful method for evaluating the discrepancy between informants who say they employ recommended hygienic practices for the prevention of diarrheal diseases and informants who actually employ them consistently in their household routines. The use of such studies as a method for monitoring compliance with public health and hygiene programs may indicate the need to intensify educational efforts for prevention of diarrhea associated with enteric pathogens that cannot be controlled by drugs alone.

Acknowledgments. This research was supported in part by a grant from Sigma-Xi, The Scientific Research Society (Research Triangle Park, North Carolina, United States).

\section{REFERENCES}

1. United States of America, Centers for Disease Control. Cholera-Peru, 1991. MMWR Morb Mortal Wkly Rep. 1991;40(6):108-110.

2. Jiménez Corona A, Gutiérrez Cogiot L, López Moreno S, Tapia Conyer R. El cólera en México: situación epidemiológica actual. Gac Med Mex 1995;131:363-366.

3. Pan American Health Organization, Disease Prevention and Control. Cholera prevention and control. Technical information from the Communicable Diseases Program. Available from: http://165.158.1.110/english/hcp/hct01. $\mathrm{htm}$ [Internet site]. Accessed 29 May 2002.

4. México, Secretaría de Salud. Cólera en México. Epidemiología Boletín Semanal 1994;1 (49):1-10.

5. Sotta P de la, Riquelme A, Silva B, Tassara R, Muñoz P, López L. Enteroparasitosis en Santi- ago poniente en relacion a la campaña de prevención del cólera. Parasitol al Día 1996;20: 27-31.

6. México, Instituto Nacional de Estadística, Geografía e Informática. Tamaulipas conteo de población y vivienda 1995. Resultados definitivos. Tabulados básicos. Aguascalientes, México: Instituto Nacional de Estadística, Geografía e Informática; 1996. 
7. México, Instituto Nacional de Estadística, Geografía e Informática. Anuario estadístico del estado Tamaulipas, edición 1996. Aguascalientes: Instituto Nacional de Estadística, Geografía e Informática; 1996.

8. Sloss MW, Kemp RL, Zajack AL. Veterinary clinical parasitology. 6th ed. Ames, Iowa, United States of America: Iowa State University Press; 1994

9. Ash LR, Orihel TC. Atlas of human parasitology. 3rd ed. Chicago, Illinois, United States: American Society of Clinical Pathologists Press; 1990.

10. Garcia LS, Bruckner DA. Diagnostic medical parasitology. 2nd ed. Washington, D.C: American Society for Microbiology; 1993.

11. Price DL. Procedure manual for the diagnosis of intestinal parasites. Boca Raton, Florida, United States: CRC Press; 1994.

12. Epidemiologic Research and Information Center. Cross-sectional studies. ERIC Notebook 1999;(7):1-4. Available from: http:// www. sph.unc.edu/courses/eric/eric_notebooks. htm [Internet site]. Accessed 15 December 2002.

13. Beaver PC, Jung RC, Cupp EW. Clinical parasitology. 9th ed. Philadelphia, Pennsylvania, United States: Lea and Febiger; 1984.

14. Bundy DAP, Wong MS, Lewis LL, Horton J. Control of geohelminths by delivery of tar- geted chemotherapy through schools. Trans $\mathrm{R}$ Soc Trop Med Hyg 1990;84:115-120.

15. Bennett A, Guyatt H. Reducing intestinal nematode infection: efficacy of albendazole and mebendazole. Parasitol Today 2000;16:71-74.

16. Mason PR, Patterson BA. Epidemiology of Hymenolepis nana infections in primary school children in urban and rural communities in Zimbabwe. J Parasitol 1994;80:245-250.

17. Albert JM, Neira M, Motarjemi Y. The role of food in the epidemiology of cholera. World Health Stat Q 1997;50:111-118.

18. Moy G, Hazzard A, Käferstein F. Improving the safety of street vended food. World Health Stat Q 1997;50:124-131.

19. Comacho SPD, Ruiz AC, Peraza VS, Ramos MLZ, Medina MF, Lozano R, et al. Epidemiologic study and control of Taenia solium infections with praziquantel in a rural village of Mexico. Am J Trop Med Hyg 1991;45:522-531.

20. Flores Castañeda M, Yáñez Rodríguez A, Torres López E. Enteroparasitosis en una población estudiantil del área metropolitana de Monterrey, N.L. Boletín Epidemiológico Fronterizo 1991;5:1-5.

21. Sarti E, Schantz PM, Plancarte A, Wilson M, Gutierrez IO, Lopez AS. Prevalence and risk factors for Taenia solium taeniasis and cysticercosis in humans and pigs in a village in More- los, Mexico. Am Jour Trop Med Hyg 1992;46: 677-685.

22. Vargas Mena J, Villarreal AC, Montes E. Frecuencia de parásitos intestinales en el estado de Nuevo León, México: I, índices coproparasitoscópicos en diez municipios del norte del estado. Rev Latinoam Microbiol 1970;12 27-33.

23. Vargas Mena J, Rodríguez ME, Montes E. Frecuencia de parásitos intestinales en el estado de Nuevo León, México: II, índices coproparasitoscópicos en nueve municipios del oriente del estado. Rev Latinoam Microbio 1970;12: 35-39.

24. Montessori GA, Bischoff. Searching for parasites in stool: once is usually enough. Can Med Assoc J 1987;137:702.

25. Senay H, MacPherson D. Parasitology: diagnostic yield of stool examination. Can Med Assoc J 1989:140:1329-1331.

26. Kawatu D, Lees RE, Maclachlan RA. Screening for intestinal parasites. Is a single sample valid? Can Fam Physician 1993;39:1748-1750.

Manuscript received 19 July 2002. Revised version accepted for publication 21 February 2003.
RESUMEN

\section{Prevalencia de la infestación endoparasitaria en niños y su relación con los esfuerzos para la prevención del cólera en México}

Objetivos. Evaluar si un mejor conocimiento y una mayor aplicación de las medidas de salud pública fomentadas para la prevención del cólera se reflejan en una menor prevalencia de infestación parasitaria en el medio doméstico de una comunidad del estado de Tamaulipas, México, cercano a la frontera con los Estados Unidos de América. Métodos. Entre 1994 y 1997 se recolectaron muestras fecales de 438 niños mediante un muestreo por conveniencia. Estas muestras fueron examinadas en busca de huevos o larvas de helmintos y quistes de protozoos, como indicadores biológicos del cumplimiento en el medio doméstico de las medidas recomendadas para la prevención del cólera. Las medidas aconsejadas consistían en lavarse las manos antes de las comidas y después de defecar, tomar agua purificada, lavar las frutas y vegetales e ingerir alimentos bien cocinados. Adicionalmente, se obtuvo información relativa al conocimiento y aplicación de las medidas para la prevención del cólera mediante entrevistas a adultos de 252 viviendas (186 de esas viviendas también entregaron muestras para análisis).

Resultados. De los 438 niños, 131 (30\%) presentaron infestaciones parasitarias. Estos niños residían en 79 (42\%) de las 186 viviendas que entregaron muestras fecales. Giardia lamblia representó el $12,5 \%$ de las infestaciones. También se encontraron $H y-$ menolepis nana, Ascaris lumbricoides, Trichuris trichiura, Enterobius vermicularis, Ancylostoma/Necator, Strongyloides stercoralis, Entamoeba coli, Entamoeba hartmanni, Entamoeba histolytica, Endolimax nana e Iodamoeba bütschlii. Los niños con parasitosis eran mayores y con mayor frecuencia tenían algún hermano o hermana infestado. Las viviendas con tres o más niños presentaron mayor probabilidad de tener algún niño infestado. Las personas encargadas de cuidar la salud en las viviendas donde había al menos un niño con parasitosis se caracterizaron por no poder mencionar de memoria al menos tres medidas de prevención contra el cólera.

Conclusiones. La prevalencia de viviendas con niños infestados con parásitos (42\%) fue relativamente elevada e indica que algunos residentes de esta comunidad pueden no haber respondido totalmente a los esfuerzos de educación sanitaria promovidos para la prevención del cólera. La presencia de protozoos parasitarios no patógenos, como Endolimax nana, Entamoeba coli, Entamoeba hartmanni o I. bütschlii, es un marcador biológico importante de la persistencia de hábitos higiénicos inadecuados que aumentan el riesgo de cólera y otras enfermedades infecciosas de transmisión fecaloral. La información obtenida de estudios similares puede servir para vigilar el cumplimiento de los programas de salud e higiene comunitarias, e indica que es necesario intensificar el trabajo educativo dirigido a la prevención de la diarrea asociada con patógenos entéricos que no pueden ser controlados solo con medicamentos. 